our pursuit of the aims defined by His Royal Highness, and on all these counts we now desire to express to Your Majesty our humble gratitude. J. H. Jeans, President." The following reply was received from Sir Clive Wigram : "I am commanded by the King to thank the members of the British Association for the Advancement of Science for the loyal message which they have addressed to His Majesty, their Patron, from the Inaugural General Meeting in the Ancient City of Aberdeen. His Majesty appreciates their kind remembrance of the occasion when the Prince Consort, as President of the Association, delivered a message from Queen Victoria to the members assembled in this City three quarters of a century ago. The King desires me to assure the members of his unabated interest in their Meetings and his confidence that their investigations into the manifold problems confronting present day Scientists will continue to be productive of results which will benefit mankind. Clive Wigram."

THe report of the Council of the British Association, adopted by the General Committee at Aberdeen on September 5, records that the Local Committee for the Leicester meeting has presented the sum of $£ 1,000$ to the Association, being the unexpended balance of the fund raised locally for the purposes of the meeting. This gift has been gratefully accepted, and the sum will be invested to form a Leicester and Leicestershire Fund, the interest of which will be used "to assist by scholarship or otherwise a student or students working for the advancement of science". Five new members of Council were elected by the General Committee, namely, Sir T. Hudson Beare, Prof. A. V. Hill, Dr. W. W. Vaughan, Dr. W. T. Calman and Prof. H. M. Hallsworth. Future meetings of the Association will be at Norwich, 1935 (September 4-11); Blackpool, 1936 ; Nottingham, 1937; Cambridge, 1938; Dundee, 1939 or 1940. Sir Josiah Stamp announced at the conclusion of the inaugural meeting at Aberdeen that the membership for the meeting had reached a total of 2,784 .

\section{Causation of Cancer}

IN a paper published in Medizinische Welt of August 25, Dr. W. von Brehmer claims to have obtained in pure culture an organism, present in the blood of cancorous patients and of animals bearing tumours. The organism could also be obtained from human and animal tumours. It is a pleomorphic aerobe which in pure culture appears in the form of tubules $0.5 \mu-2.8 \mu$ long and $0.2 \mu-0.8 \mu$ broad, and can be stained by a Giemsa stain. The tubules are filled with spores, which when liberated, are stated to be able to enter damaged cells and thus cause cancer. An essential condition for obtaining cultures of this organism, to which the name Syphonospora polymorpha has been given, is an alkaline condition of the medium, with a $p H$ of $7 \cdot 5-7 \cdot 6$, and von Brehmer maintrins that cancer is always associated with a shift of the hydrogen ion concentration of the blood toward the alkaline side. The organism is stated to exist in the blood of apparently normal healthy people in the form of small spores which are non-pathogenic, but become pathogenic with the shift of the hydrogen ion concentration. Dr. von Brehmer also claims to have produced tumours in animals by the injection of pure cultures of his organism, but no detailed evidence is given.

Dr. von BreHMer's paper is followed by a paper by $V$. Schilling, who has repeated these experiments, partly with von Brehmer's assistance. He has succeeded in obtaining pure cultures of this organism from malignant tissues and from the blood of cancer patients and of animals bearing tumours. His experiments on the production of cancer in animals by inoculation of these tumours have, however, given negative results. $\mathrm{He}$ is, therefore, inclined to regard the presence of this organism as being due to a mixed infection or to its being a non-pathogenic symbiont, and he dissociates himself from the therapeutic and diagnostic conclusions drawn by von Brehmer from his work. The existence of a relatively large, visible and stainable organism as the cause of cancer is difficult to reconcile with many of the well. established facts concerning cancer. Moreover, the existenee of an alkalosis in cancer, which von Brehmer considers to be an essential feature of cancer, is questionable and several competent obsërvers using exact methods have failed to demonstrate it. It has been reported (Times, September 10) that von Brehmer's claims will be submitted to an official investigation, initiated by the authorities in Germany. Until the results are known, it is necessary to reserve judgement.

\section{Food Storage and Transport}

ON September 7, Sir Frank Smith, Secretary of the Department of Scientific and Industrial Research, delivered the Hardy Memorial Lecture before the British Association at Aberdeen, in which he paid tribute to the work of the late Sir William Hardy, who during the last seventeen years of his life, devoted much of his time to research on the transport and storage of foodstuffs. Sir Frank described the work being done on the kippered herring at the Torry Research Station, Aberdeen, which was founded by Sir William Hardy. A now kippering kiln has been evolved there, in which all variables such as temperature, humidity, etc., can be controlled. Thus, any desired cure can be produced with certainty. At the same station, a new kind of mild salted herring has been produced by the combined processes of salting and chilling. About 1,600 steam trawlers fish from the ports of Great Britain, landing nearly 700,000 tons of white fish valued at about $12 \frac{1}{2}$ million sterling each year. Storage in crushed ice, under conditions prevailing when Hardy took up the problem in 1929, could only hold such fish fresh for 6-7 days. To-day, work at the Torry Station has extended that period to 12 days, by reducing bacterial contamination. Further work has shown that freezing in brine at $-20^{\circ} \mathrm{C}$. and storing at the same temperature will keep the fish for three months. The 10,000-ton vessel Arctic Queen, fitted as a floating factory for halibut, was also described. The importance of refrigeration cannot be over- 
emphasised in connexion with food storage and transport. Sir William Hardy's fruitful work along these lines was fittingly described by Sir Frank. Thanks largely to the work of Sir William, it is realised to-day that the biologist must formulate the condition required in food storage and transport, and the engineer provide those conditions. The problems of the biologist concern not only methods of refrigeration itself, but also cleanliness, damage to foods by cold, etc. The most recent developments in gas storage using carbon dioxide, and in the storage of living material such as fruit, were also discussed by Sir Frank.

\section{Cleansing of Oysters}

THE cleansing of oysters on a commercial scale has now been accomplished after a period of some fifteen years' continuous research work at the Conway Experimental Station of the Ministry of Agriculture and Fisheries. A purification station has been established at Brightlingsea, and since May has produced 'certified' American and Portuguese oysters. The principles of the process are almost the same as those involved in the cleansing of mussels, namely, a thorough preliminary cleansing of the outside of the shell is followed by a first and then a second bath in sterilised water. During immersion in the baths the oysters cleanse themselves internally and externally (that is, the external soft parts inside the shell) of bacteria in a simple way; the internal bacteria are expelled. from the gut in the fæces, the external in mucoid films which are gleaned from all parts by cilia to be collected and extruded in masses as pseudo-fæces. After each bath, the shells are thoroughly washed to remove the excreta and are finally treated with water containing three parts in a million of free chlorine to destroy any remaining adherent germs. An essential feature of the oyster-cleansing process consists in the use of water at a temperature not less than $56^{\circ} \mathrm{F}$., as it was found after a long series of experiments that ciliary activity below this temperature could not be relied upon to effect perfect cleansing. Mussels can be reliably purified in water which does not fall below $39^{\circ} \mathrm{F}$. The English native (or European) oyster (Ostrea edulis) has been purified in a process involving three baths, and differs otherwise in its reactions from the American and Portuguese. It is reported that purified $O$. edulis may be produced in the coming winter. The summer capacity of the tanks is 360,000 oysters per week, but in winter when the sea-water requires to be warmed, the capacity is halved. Full details of the process and the plant are not yet available, but may be published in the near future.

\section{The Droitwich Broadcasting Station}

IN the presence of representatives of the Press, the new B.B.C. transmitting station at Droitwich was formally opened on September 6, to take over a part of the National broadcasting programme, This station will ultimately provide a full national programme from the long-wave transmitter which is now working, and also a regional service for the Midlands from a medium wave transmitter which will be completed in about six months' time. The programme transmitted from the new station on the opening day was heard in London very clearly, and its volume was considerably greater than that of tho London National transmitter at Brookman's Park. It is expected that the new long-wave station will give a service of such quality over so large an area of Great Britain that three other national stationsthose for London, the West and the North-will not need to go on broadcasting. The wave-lengths thus released may be used for other British stations to be erected in the future. The wave-length of the new Droitwich transmitter is identical with the long-wave Daventry station so that no change is required in listener's receiving sets.

THe issue of World Radio of September 7 contains an illustrated technical description of the new transmitting station at Droitwich, by Mr. Noel Ashbridge, chief engineer of the B.B.C. This transmitter has an aerial input power of $150 \mathrm{kw}$., five times as great as that of Daventry. The whole of the power for the station is generated by heavy oil engines, and these prime movers together with the electrical machines and their control equipment occupy a considerablo proportion of the space in the station buildings. The long-wave wireless transmitter consists of five units, by means of which, weak oscillations of a carefully controlled radio frequency are amplified up to a final output power of $150 \mathrm{kw}$. Modulation is carried out at the penultimate stage by varying the hightension supply to the anodes of the high-frequency valves, with which the modulating valves are in series. This method of modulation, together with a special output circuit arrangement, makes it possible for this transmitter to emit broadcasting programmes of a much superior quality to that hitherto possible from a long-wave station. The quality of the transmissions from Droitwich is expected to be at least equal to, and probably better than, those at present obtainable from the medium-wave stations. The new station is now radiating the morning National programme from 10.15 A.M. until 11.55 A.M. and the late dance music every week-day; it will continue to do this until it takes over the full service of the National programme from Daventry in October.

\section{Edinburgh Geological Society Centenary}

THE centenary of the Edinburgh Geological Society was celebrated on Monday and Tuesday, September 3 and 4. A considerable number of invitations had been sent out to kindred societies and institutions both at home and abroad, and a most gratifying response was received. On Monday morning the delegates were received by the president of the Society, Sir John Flett. Naturally the majority came from Scotland and England, but out of a total of sixty visitors, thirteen came from the Continent, nine represented the Colonial Empire, and four the United States of America. Following this reception, the whole party, including many fellows of the Society, had lunch in the city and proceeded to visit the Royal Scottish Musoum, where the various exhibits were demon- 